\title{
FIRST REPORT ON PLANT GALLS (ZOOCECIDIA) FROM MANGROVE SWAMPS OF VIKHROLI, MAHARASHTRA
}

\author{
R.M. Sharma ${ }^{1}$, P.V. Joshi ${ }^{2}$ and Mahesh Shindikar ${ }^{3}$ \\ ${ }^{1}$ Zoological Survey of India, High Altitude Zoology Field Station, Saproon, Solan, Himachal Pradesh 173211, India. \\ ${ }^{2}$ Naoroji Godrej Centre for Plant Research, Gate No. 431, Lawkim Limited Campus, Shindewadi, Shirwal, Satara, Maharashtra 412801, \\ India. \\ ${ }^{3}$ Agharkar Research Institute, G.G. Agarkar Marg, Pune, Maharashtra 411004, India. \\ Email:maheshshindikar@hotmail.com
}

\begin{abstract}
Mangrove swamps along Thane Creek (Mumbai), Maharashtra Coast were surveyed to study plant galls. Avicennia marina, Sonneratia apetala and Salvadora persica (a mangrove associate) were found subjected to gall formation.
\end{abstract}

\section{Keywords \\ Mangroves, plant galls, Thane Creek, Vikhroli}

\section{Introduction}

Recent surveys estimate the mangrove cover in India to be approximately $3150 \mathrm{~km}^{2}(0.001 \%$ of the total land area). In Maharashtra, mangrove cover is degraded (ca. $124 \mathrm{~km}^{2}$ ) but luxuriant pockets can still be found (Untawale \& Jagtap, 1998).

Plant galls are comparatively very rare in mangroves. This may be due to relatively high salt concentration in the internal tissue of mangrove plants, which is inimical to hatching of insect eggs and subsequent growth of the larvae (Chapman, 1976). However, studies on plant galls from mangroves of Andaman Islands reveal that out of all mangrove species Avicennia marina is highly susceptible to gall formation. Sharma and Das (1984) reported eight different kinds of galls on Avicennia marina from the Andaman coast.

A survey was conducted during 2000-2001, with a view to investigate the existence of plant galls from mangroves and associated plants from Vikhroli region along Thane Creek (Fig.1).

The mangrove forest at Vikhroli extends over an area of 1062.30ha of which 718.72 ha belongs to the private trust, Sonabai Pirojsha Godrej Foundation. Out of the total area, 730ha is under mangrove vegetation and 35 ha land bears terrestrial vegetation in the physiognomic shape of scrub savanna i.e. continuous cover of fairly tall grasses, dotted with shrubs and small trees (Deshmukh, 1990). The mangrove vegetation of Vikhroli comprises species from Avicenniaceae, Euphorbiaceae, Rhizophoraceae, Acanthaceae, Myrsinaceae and Sonneratiaceae. The dominant species is Avicennia marina (Forsskal) Vierh. followed by Acanthus ilicifolius L. and Excoecaria agallocha L. with the occurrence of Aegiceras corniculatum (L.) Balnco, Bruguiera cylindrica (L.) Blume, Ceriops tagal (Perr.) Robin., Sonneratia alba Smith, Sonneratia apetala Buch.-Ham. and Derris heterophylla (Willd.) Backer. Plantations of Rhizophora apiculata Blume and R. mucronata Poiret were observed in the study area. Important mangrove associates observed include Salvadora persica L., Aeluropus lagopoides (L.) Trin., Cyperus rotundus L. ex Thwaites, Phyla nodiflora (L.) Greene, Ipomoea sepiaria Koenig ex Roxb. (Shindikar, 2002). Of all these plants Avicennia marina, Sonneratia apetala and Salvadora persica were subjected to gall formation. This is a first report on plant galls of mangroves from Maharashtra. A detailed exomorphic description of these galls is given below.

Galls on Avicennia marina caused by unknown Cecidomyiid (Diptera) (Fig. 2)

Leaf galls: Epi-hypophyllous. Discoid, compressed; glabrous; solitary or in pairs but never agglomerate; indehiscent; sessile, persistent dark brown above (initially may be greenish) but similar to the colour of leaf surface below. Gall cavity unilocular enclosing a single larva inside. Exit hole seen on the upper surface of leaf blade. Galls may arise anywhere on the leaf surface. Size of the gall varies from $4-5 \mathrm{~mm}$ in diameter. About 210 galls occur per leaf. This gall is similar to the one reported by Sharma et al. (1984) from Andaman Islands on the same species. 


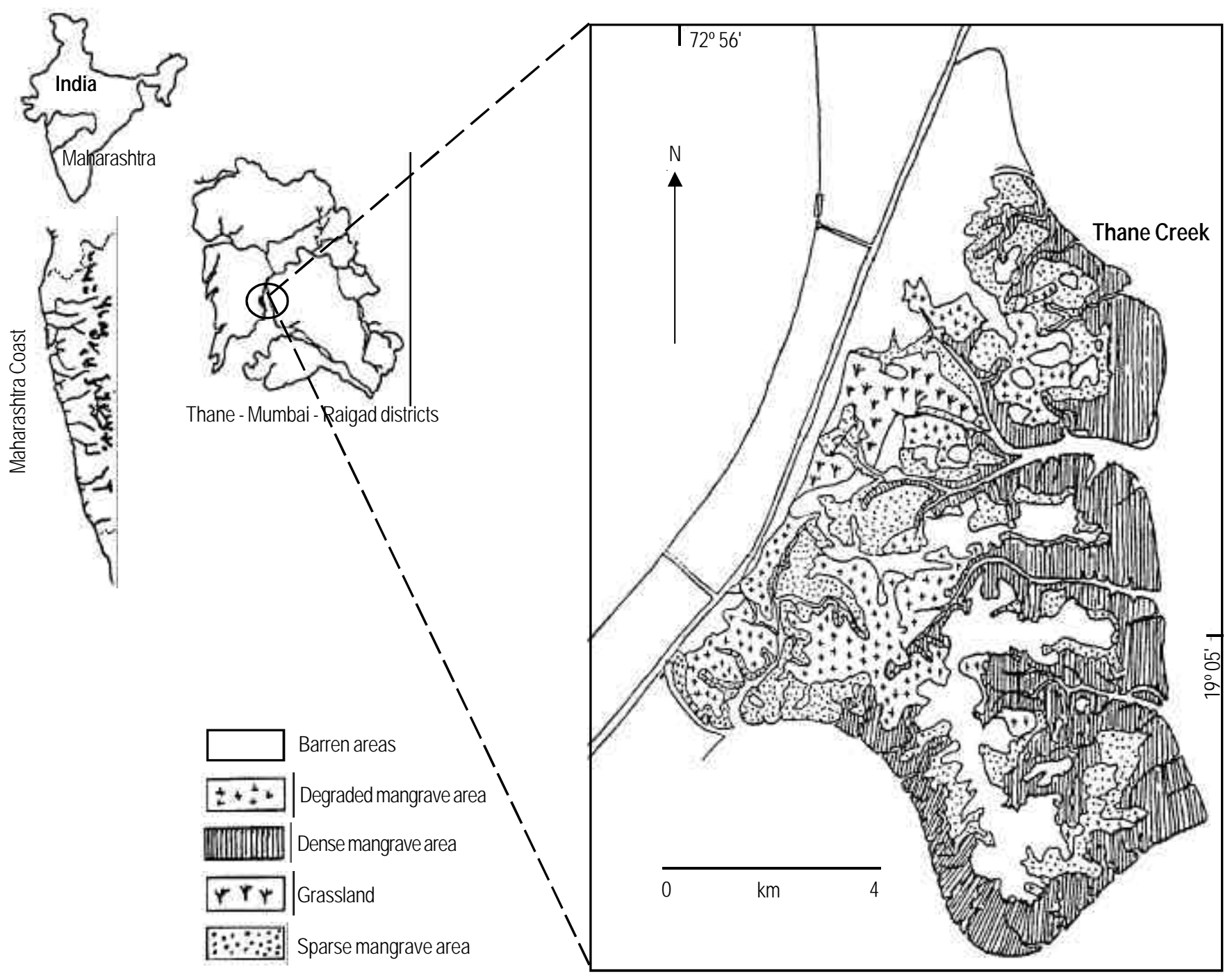

Fig. 1. Map of the Vikhroli Mangrove swamps

\section{Stem galls caused by unknown Hymenoptera (Fig. 3)}

Irregularly globose or subglobose, verrucose, solid, hard, woody, solitary or paired, indehiscent, persistent unilateral cortical gall. Light greenish-brown when young, becomes brown on aging. Gall cavity multichambered with a single larva inside each chamber. Pupation takes place in the gall itself. Size of the gall varies from 10-20mm and 1-3 galls appear on a small tender branch. Several exit holes seen on a mature gall. This gall is practically similar to the one reported by Sharma and Das (1984) on the same species from Andaman Islands.

\section{Galls on Sonneratia apetala}

caused by unidentified Microlepidoptera (Fig. 4)

Leaf fold galls. Mainly hypophyllous, rarely epiphyllous. Mostly apical portion of leaf margin gets folded downward. Galls solitary, simple, solid, glabrous, indehiscent and persistent. Gall cavity unilocular enclosing a single greenish-yellow caterpillar inside. Pupation may or may not take place inside the gall. A single gall per leaf. Sometimes whole leaf gets folded into a gall and looks like a bud. Deserted galls found to be occupied by other insects (successors) like small beetles or ants. Gall size varies from $5-12 \mathrm{~mm}$ in length and $5-8 \mathrm{~mm}$ in diameter. Heavy infestation and profuse galling was observed 

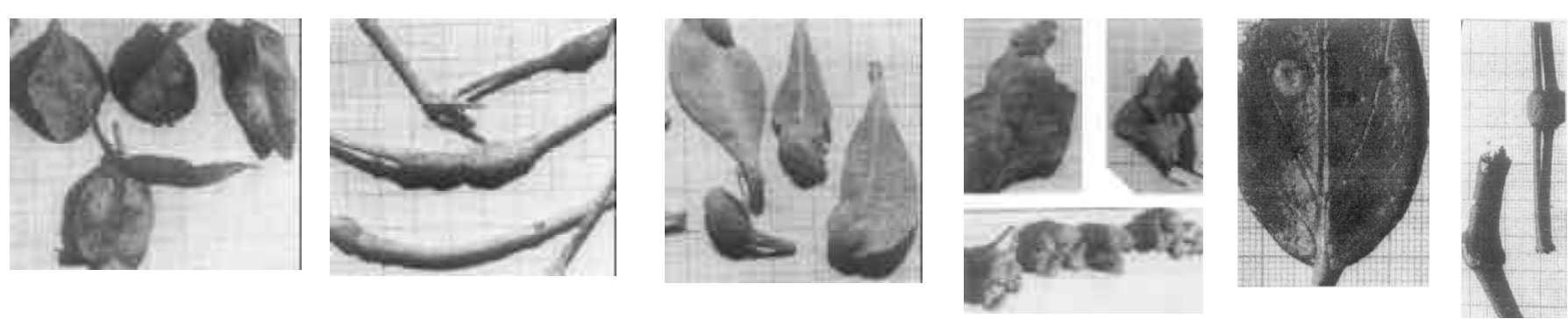

Fig. 2-7. Plant galls on various mangrove species

2 - On Avicennia marina caused by unknown Cecidomyiid (Diptera); 3 - on Avicennia marina stem galls caused by unknown Hymenoptera; 4 - on Sonneratia apetala caused by unknown Microlepidoptera (moth); 5 - on Salvadora persica caused by a mite Aceria sp. (Acarina: Eriophyidae); 6 - on Salvadora persica caused by a gall midge Thomasiniana salvadorae Rao;

7 - stem gall on Salvadora persica

on all the plants in study area. This gall is somewhat similar to the gall recorded from Andaman Islands by Sharma et al.(1983) on Sonneratia alba caused by a Microlepidoptera. However, leaf gall on Sonneratia apetala seems to be hitherto unrecorded.

\section{Galls on Salvadora persica $L$.}

a) caused by Aceria sp. (Acarina: Eriophyidac) (Fig. 5)

Leaf gall, mostly epiphyllous, globose/subglobose or sometimes irregular and agglomerated; lobed, smooth, greenish/yellowish pouch gall, with large hypophyllous gall cavity and ostiole. Gall cavity lined by fine dense erineum; moderately thick walled and coreacious, $1-4$ galls per leaf, varying from $5-15 \mathrm{~mm}$ in diameter. Mani (1973) has recorded this gall from western Uttar Pradesh and Rajasthan.

b) caused by Thomasiniana salvadorae Rao (Diptera: Cecidoinyiidae) (Fig. 6)

Leaf gall, mostly, epiphyllous, sometimes epi-hypophyllous, globose pouch gall. A few galls were found and seem to be uncommon.

\section{Stem galls (Fig. 7)}

Subglobose, ovoid or fusiform, sometimes cylindrical and moniliform, glabrous, greenish- or grayish-brown, solid, hard, woody, indehiscent, persistent, swelling on tender branches, usually $25-30 \mathrm{~mm}$ long and $10-15 \mathrm{~mm}$ thick, a single branch may harbor 5-7 separate galls. Larval chambers cylindrical leading to exit holes on the surface. Several exit holes seen on a single gall. This gall was recorded earlier from Rajasthan and western Uttar Pradesh (Mani, 1973).

\section{Acknowledgments}

Authorities of Naoroji Godrej Centre for Plant Research, Shirwal, Satara and Soonabai Pirojsha Godrej Foundation, Vikhroli, Mumbai are gratefully acknowledged for their support and research grant. Thanks are also due to the Director, Zoological Survey of India, Kolkata and the Officers-in-Charge, Western Regional Station, Pune and High Altitude Zoology Field Station, Solan for facilities and encouragements, and to Mr. Sachin Ranade for photography.

\section{References}

Chapman, V.J. (1976). Mangrove Vegetation i-viiil, J. Cramer, 1447.

Deshmukh, S. (1990). Ecological Studies on Mangroves in Bombay, Ph.D. Thesis. University of Bombay, 153pp (unpublished).

Mani, M.S. (1973). Plant Galls of India. Macmillan, India, 354pp. Sharma, R.M., M.K.D. Roy and A.K. Das (1983). New records of Zoocecidia from mangroves of Andaman Islands, India. Geobios 2: 139-141.

Sharma, R.M. and A.K. Das (1984). Further contribution to the knowledge of Zoocecidia of mangrove Avicennia marina (Forsk.) Vier. Records of the Zoological Survey of India 81(3\&4): 123-126.

Sharma, R.M., M.K.D. Roy, B. Mitra and A.K. Das (1984). New Records of Zoocecidia on the mangrove, Avicennia marina (Forsk) Vier. from Andaman Islands, India. Geobios 3: 46-48.

Shindikar, M.R. (2002). Status and Ecological Studies on Mangroves of Thane Creek, M.Phil. Dissertation. University of Pune (unpublished).

Untawale, A.G. and T.G. Jagtap (1998). Mangroves, no waste lands, pp.71-74. In: The Hindu Survey of India, 98pp. 